\title{
FARM STRUCTURE AND EFFICIENCY IN THE HUNGARIAN AGRICULTURE
}

\section{Orsolya Tóth ${ }^{1 *}$, István Takács ${ }^{2}$}

\author{
${ }^{1}$ Research Institute of Agricultural Economics, Budapest, Hungary \\ ${ }^{2}$ Károly Róbert College, Institute of Business Sciences, Gyöngyös, Hungary
}

\begin{abstract}
It has long been the subject of empirical researches to examine the technical efficiency on farm (micro) level. Two main methods are most often used in the empirical literature: the non-parametric Data Envelopment Analysis (DEA) based on linear programming, and the Stochastic Frontier Analysis (SFA) introduced by Aigner, Lovell and Schmidt (1977). The present study aimed to investigate the technical efficiency of farms involved in agricultural activities in Hungary using the DEA-method and the data from the Hungarian FADN database. The technical efficiency was examined based on legal forms, farm size categories and the type of farming between 2001 and 2013.
\end{abstract}

Keywords: agriculture, DEA-method, FADN, technical efficiency

\section{Introduction}

Major economic and social changes have taken place in Hungarian agricultural economy in the last seven decades. The development of agricultural economy has experienced sometimes radical and opposite effects of economic and social policy decisions. About these changes it can be stated that acting governments have been strongly influencing the normal economic processes without allowing enough time for impact assessment analysis. Moreover, the professional advice often disturbed their political preconceptions, thus the changes have ignored rationality in many cases.

The consecutive decisions have mostly transformed in opposite directions the ownership of farming activities, the holding structure and the organizational forms. The development and operation of a different farming structure has generated much tension, many economic and social losses, which have been manifested in deteriorating of capital endowment, critically low profitability and the reduction of technological level in agriculture, as well as increasing living problems of the (mostly) rural population whose subsistence depends on agriculture.

The farm structure has undoubtedly become more diverse and more flexible in the decades following the regime change. Unfortunately there are many unfavourable factors (fragmented holding structure, dual farm structure, and low level of employment, livelihood, technical and technological development), which are permanently present in the sector. The transformation process in the transition period is vastly examined in literature. The effects of structural changes on efficiency, profitability and competitiveness of Hungarian agricultural economy have been neglected.

The most important argument supporting the relevance of this topic is that it had been accumulating many experiences in the last two decades of the transition enabling us the examination of the main features of the changed farm structure. The actuality of the topic is also supported by the fact that Hungary joined the EU during this period and the adverse consequences of the world economic crises experienced in the recent years. It is important to investigate what kind of farming groups were formed based on the size of agricultural land, legal form, type of farming, economic performance and what rearrangements and changes can be seen in their management during the past two decades.
Efficiency-calculations were made in the article using the outputoriented DEA-method to show which farming groups were efficient and which were not between 2001 and 2013 in Hungarian agriculture. We have first assumed that with the increasing farm size, the technical efficiency has also been improving and second, the technical efficiency of crop production is lower compared to animal husbandry. The results have shown that if we examined all the farms in the sample, the technical efficiency would be very low.

There are many literature sources dealing with technical efficiency, but this article is unique because earlier none of the authors analysed technical efficiency based on these many factors (legal form, type of farming, farm size). The article will show other studies in connection to the topic in the following.

Hockmann and Pieniadz (2007) examined the technical and size efficiency of Polish agriculture based on FADN data and they found out that in spite of the small-scale structure of Polish agriculture it did not suffer from problems of size.

Fogarasi and Latruffe (2009) examined the difference in technical efficiency and potential technology gap between French and Hungarian dairy farms during 2001-2006, using the Data Envelopment Analysis under each country's respective frontier and under a common frontier (metafrontier). The results indicated that French farms have a more optimal scale of production than Hungarian farms, but Hungarian farms make better use of technology. They also have a more productive technology than French farms.

Bakucs et al. (2011) analysed and compared various efficiency indicators (like technical efficiency analysis, total factor productivity analysis, and ordinary least squares on time trend) for a number of European Union (EU) countries: Belgium, Estonia, France, Germany, Hungary, Italy, The Netherlands, and Sweden. Their main results were the following. Generally, all countries had relatively high levels of mean technical efficiency ranging from 0.72 to 0.92 for both field crops and dairy farms. Interestingly, the majority of countries had better performance in dairy sectors in terms of higher levels of mean efficiency than in field crop production. Stability analysis revealed that in average, $60 \%$ of farms maintained their efficiency ranking in two consecutive years, whilst $20 \%$ improved and $20 \%$ worsened their positions for all countries. The authors decomposed the total factor productivity changed into its main elements. Field crop farm indicators generally presented significantly 
higher volatility than dairy farms. Random effect panel regression of the Total Factor Productivity Change on its components showed Technological Change as being the significant positive driver for crop farms, whilst Technical Efficiency Change followed by Technological Change are the most important for dairy farms. In addition, they did not find significant impacts of CAP reforms in 1992 and 2000 on the total productivity changes.

Baráth and Fertő (2014) stated that there is a clear lack of investigations into the agricultural TFP level in the new member states (NMS) and there is limited information about the level of agricultural TFP in the EU after 2007. They decomposed agricultural productivity indexes for the European agriculture from 2001-2010 and analysed whether there is a convergence or divergence between the old (OMS) and the new member states (NMS) in terms of TFP levels. Their results were the following: the highest level of TFP was in Spain, both in 2000 and 2010, whilst the lowest level was in both years in Finland. Additionally, it could be seen that the biggest change regarding TFP between 2000 and 2010 was in Poland, where there was a 124\% increase in TFP, the estimated TFP increased in Poland due to a 3\% increase in technical change and a $20 \%$ increase in overall efficiency.

Kapronczai et al. (2014) examined the changes in profitability and efficiency of Hungarian farms after the EU accession and the authors stated that Hungarian agriculture has some benefits due to the accession to the European Union. The sector's income position has steadily improved, and the competitiveness of agriculture has also increased in the last ten years.

This article examines the technical efficiency in Hungarian farms between 2001 and 2013. The results and the examined literature sources have shown that there is no considerable lack in terms of technical efficiency compared to the European Union. Chapter 2 presents the material and methods and the results are presented in Chapter 3. Conclusions can be read in Chapter 4.

\section{Material and methods}

Based on literature sources those farms are considered to be efficient the production of which reaches the limit of production possibilities that is the level of production which is available at the current time using the current technology is not possible to produce more. The investigation was carried out with output-oriented efficiency calculations using the DEA-method.

The Data Envelopment Analysis (DEA) is one of the most important approaches to measuring efficiency. Since its advent in 1978 (Charnes et al., 1978), this method has been widely utilised to analyse relative efficiency, and has covered a wide area of applications and theoretical extensions (Allen et al., 1997).

The DEA (Data Envelopment Analysis), developed by Charnes, Cooper and Rhodes (1978), is a non-parametric technique for evaluating the technical efficiencies of a collection of "Decision Making Units (DMUs)" which consume common inputs to generate common outputs. The DEA is widely acclaimed as a useful technique for measuring efficiency, including production possibilities, which are deemed to be one of the common interests of Operational Research and Management Science (Charnes et al., 1994).

Based on the definition of efficiency, the DEA is a mathematical optimization technique which determines the efficiency of each DMU by maximising the ratio of a weighted sum of its outputs to a weighted sum of its inputs while ensuring that the efficiencies of other units do not exceed $100 \%$. The DEA-method is based on a model of linear programming in order to define the technical efficiency levels, in cases of constant or variable returns to scale.

The implementation of the DEA-based linear programming can be implemented as follows (Cooper et al., 2000):

$$
\left[d_{0}^{t}\left(q_{t^{\prime}} x_{t}\right)\right]^{-1}=\max \phi \lambda \Phi
$$

where:

$-\phi q_{i t}+Q_{t} \lambda \geq 0$

$x_{i t}-X_{t} \lambda \geq 0$

$\lambda \geq 0$

$$
\left[d_{0}^{s}\left(q_{s^{\prime}} x_{s}\right)\right]^{-1}=\max \phi \lambda \Phi
$$

where:

$-\phi q_{\text {is }}+Q_{s} \lambda \geq 0$

$X_{i t}-X_{s} \lambda \geq 0$

$\lambda \geq 0$

$$
\left[d_{0}^{t}\left(q_{s^{\prime}} x_{t}\right)\right]^{-1}=\max \phi \lambda \Phi
$$

where:

$-\phi q_{i s}+Q_{t} \lambda \geq 0$

$x_{i s}-X_{t} \lambda \geq 0$

$\lambda \geq 0$

$$
[\mathrm{d} 0 \mathrm{~s}(\mathrm{qt}, \mathrm{xt})]-1=\operatorname{maxflF}
$$

where:

$-\phi q_{i t}+Q_{s} \lambda \geq 0$

$x_{i t}-X_{s} \lambda \geq 0$

$\lambda \geq 0$

where:

$i \quad-$ farm $i$

$N \quad$ - number of observations

$Q_{t} \quad-$ matrix $(M \times N)$ form

$t \quad$ - number of times (years)

$X_{t} \quad-$ matrix $(K \times N)$ form

$\lambda$ - weighting vector $(N \times 1)$ form

$\varnothing \quad$ - scalar

These four linear programming tasks have to be solved for each farm and for each period.

The observations (farms) are located in the area under the curve in the output-oriented DEA model (with two inputs and one output). The curve shows the combinations of the various outputs. Points $A, B, C$ and $P^{\prime}$ indicate an efficient production along to boundary line, while the efficiency represented by points $P$ and $Q$ can be improved along the respective lines.

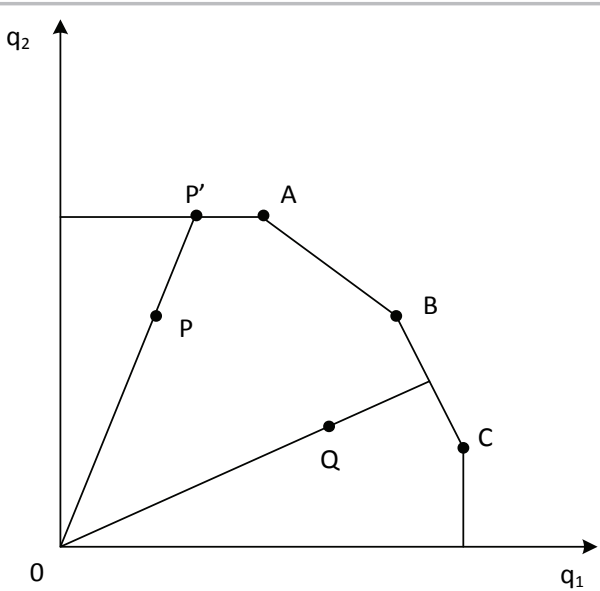

Figure 1 The schematic representation of the output-oriented DEA model Source: Own edition, 2015 
Table 1 The average data of the individual and the corporate farms between 2001 and 2013

\begin{tabular}{|l|c|c|}
\hline Denomination & Individual farms & Corporate farms \\
\hline Average sample size in piece & 1493 & 428 \\
\hline Average output* in HUF & 16860 & 244390 \\
\hline Average agricultural area in ha & 86.3 & 340 \\
\hline Average employment in AWU & 1.96 & 21.3 \\
\hline Average material costs in HUF & 7456 & 111808 \\
\hline Average depreciation of fixed assets in HUF & 39150 & 219700 \\
\hline Average livestock in LU & 18.8 & 39.1 \\
\hline
\end{tabular}

Notes: * Gross value of production minus the value of subsidies

Efficiency was calculated based on the DEA-method in the following output and input data:

$\square$ output: gross value of production minus the value of subsidies,

$\square$ input 1: agricultural area (ha),

$\square$ input 2: agricultural employment (AWU),

$\square$ input 3: material costs (HUF),

$\square$ input 4: depreciation of fixed assets (HUF),

$\square$ input 5: livestock (LU).

Database used: FADN Hungary between years 2001 and 2013.

\section{Descriptive statistics on the sample}

The examined sample size changes from year to year. The article did not use a panel dataset because the sample size would have largely reduced. We summarized the average data of the individual and the corporate farms in Table 1. As we can see, the individual farms are in majority in the sample. The average agricultural area has shown significant difference between the legal forms. Crop production is characteristic by the corporate farms, and animal husbandry is more often by the individuals.

The agricultural employment is higher by the corporate farms because the individuals usually do not account the cost of labour of family members.
Corporate farms received much more agricultural subsidies per hectare than the individual farms (excluding investments subsidies which cannot be regarded as income). The reason for this is that corporate farms can much better utilise the funds available through tendering.

The minimum, maximum and standard deviation values by the individual and corporate farms were summarized in Table 2 . It is interesting to note that there are huge differences between legal forms by all of the examined factors. There Source: Own edition based on FADN data, 2015 are much more individual farms in the database than corporate farms. Hungarian agriculture shows a bipolar farm structure in which the role of individuals is more pronounced.

\section{Results and discussion}

In terms of the changes of technical efficiency it can be stated that the technical efficiency of the farms have continuously improved year by year until 2006 and then a decline had occurred for 3 years (Figure 2). A modest improvement has happened in 2010 and 2011 and later, between 2011 and 2012, a slight decline in terms of the technical efficiency occurred. A minor technical efficiency improvement can be demonstrated from 2012 to 2013. It is important to emphasize that the figure is based on the full FADN sample. We did not distinguish between legal form, farm size or type of farming. As follows, the main results are presented differentiated by legal form, size and type of farming (arable crop production, pig breeding, dairy farming, and fruit production).

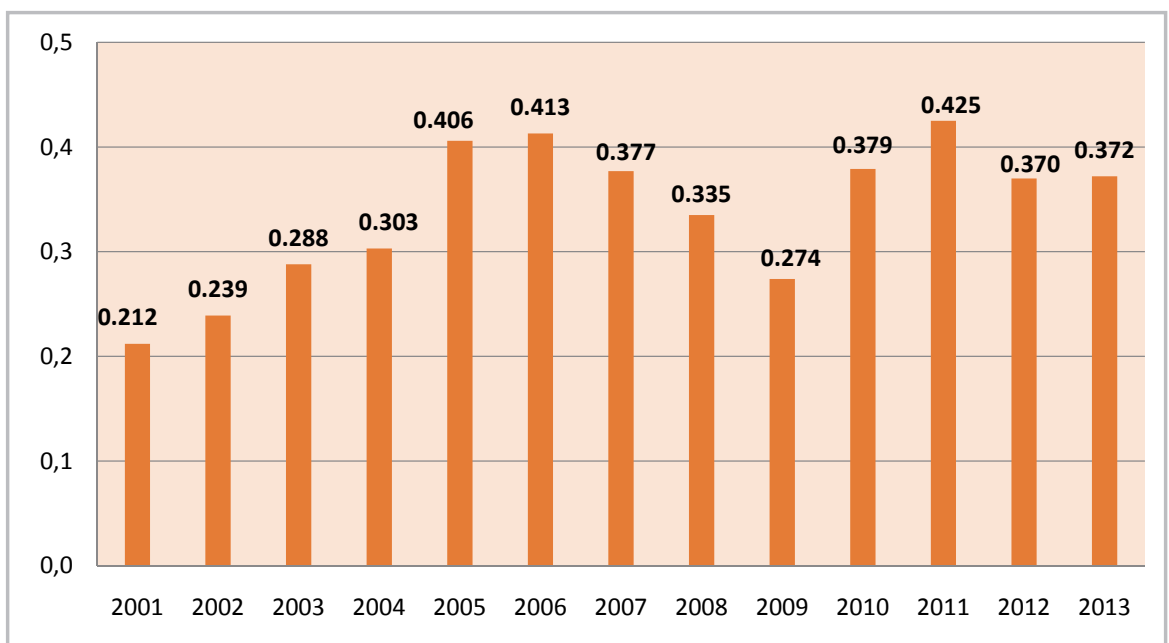

Figure 2 The technical efficiency in the total sample $(2001-2013)($ Sample $=1850)$

Table 2 The minimum, maximum and standard deviation values by the individual and corporate farms

\begin{tabular}{|l|c|c|c|c|c|c|}
\hline \multirow{2}{*}{ Denomination } & \multicolumn{3}{|c|}{ Individual farms } & \multicolumn{3}{c|}{ Corporate farms } \\
\cline { 2 - 7 } & minimum & maximum & Std. deviation & minimum & maximum & Std. deviation \\
\hline Sample size in piece & 1387 & 1599 & 1450 & 365 & 490 & 394 \\
\hline Output* in HUF & 59.12 & 363088 & $23,133.4$ & 396.6 & $4,657,585$ & 465,423 \\
\hline Agricultural area in ha & 0.04 & 1000 & 107.12 & 0.21 & $9,064.2$ & $1,033.1$ \\
\hline Employment in AWU & 0.01 & 19.7 & 1.9 & 0.10 & 319.2 & 32.6 \\
\hline Material costs in HUF & 30.7 & 225642 & $11,847.5$ & 224.2 & $2,432,928$ & $244,590.8$ \\
\hline Depreciation of fixed assets in HUF & 193.2 & 446826 & $51,101.8$ & 71.7 & $5,110,354$ & $440,184.9$ \\
\hline Livestock in LU & 0.0 & 186.2 & 115.6 & 0.0 & $14,612.9$ & 511.7 \\
\hline
\end{tabular}

Notes * Gross value of production minus the value of subsidies 


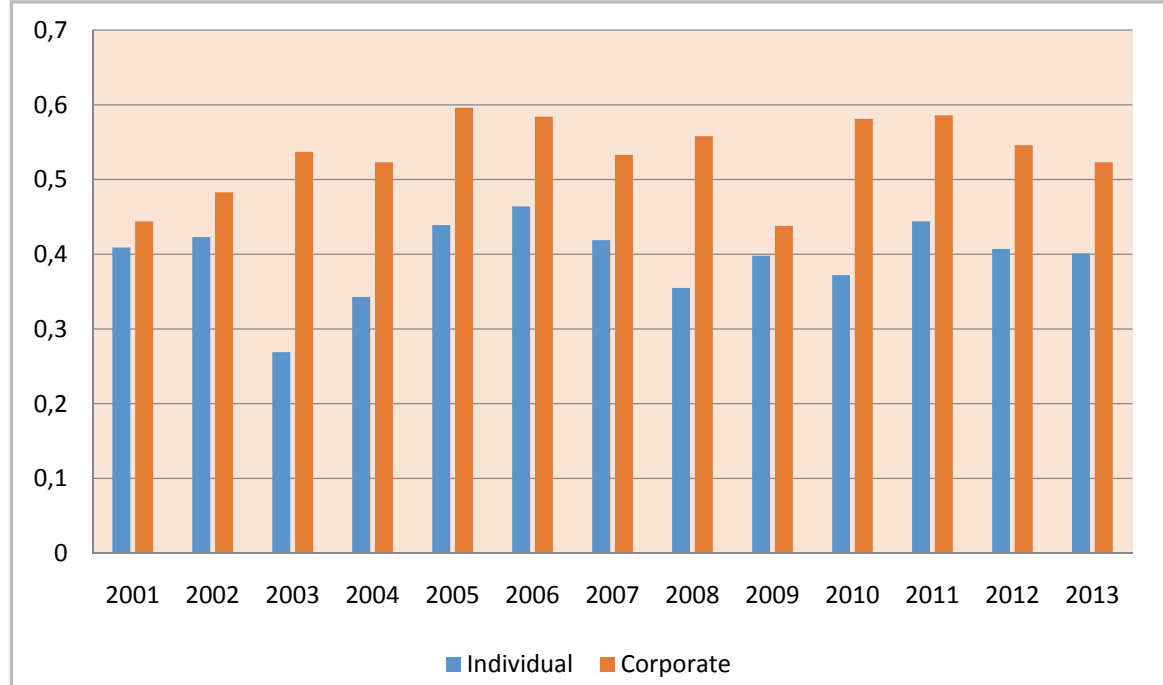

Figure 3 Improvement of technical efficiency by legal forms (2001-2013) Source: Own edition based on FADN data, 2015
The global financial crisis followed by the economic crisis has seriously affected not only Hungarian economy, but also its agricultural sector. The impact of the economic downturn has also manifested in the decreasing of the employment, in the declining investments, and the hectic exchange rate alteration.

The technical efficiency was significantly reduced by 7 percentage points in 2009 compared to 2008 due to the crisis. Some studies (Kemény et al., 2010; Szemán, 2011) examined the effects of the global economic and financial crisis and their results showed that due to the crisis the performance of Hungarian agriculture declined significantly. The unexpected and sudden events shocked the whole Hungarian economy.

\section{Efficiency calculations by legal forms}

The technical efficiency of the individual and corporate farms did not show much difference in the early 2000s, the values being almost the same (Figure 3). The technical efficiency of the corporate farms has increased compared to previous years in 2003, while the private farms have suffered significant setback.

The improvement of the TE indicator can be seen in the case of both legal forms after Hungary's accession to the EU. The technical efficiency of the individual farms has improved at the time of the economic crisis (in 2008 and 2009) while the TE indicator shows a decrease in the case of the corporate farms.

The technical efficiency has stagnated or a modest decline is observed for both individual (0.42) and corporate farms (0.56) at the end of the examined period (2010-2013). It is important to note that the indicator is higher in the latter group.
A methodological comment is important to be made: we only calculated efficiency with input 5 (the livestock) in relation to pig breeding farms and dairy farms. The program called DEAP calculates efficiency if there are no zero data in the sample. There is no livestock by the crop or fruit production in most cases. In this case the value of the livestock would be zero. Therefore, they would have dropped out of the sample which would thoroughly reduce the sample size.

\section{Efficiency calculations by farm size categories}

From 2010 onwards, the typology is based on the Standard Output ( $\mathrm{SO}=$ total production direct subsidies). Holdings have been classified into 14 size categories according to the European Commission regulation. Three groups were created based on the 14 SO size classes and efficiency calculations were separately made for these groups. The first group included farms belonging to the size category of 3-6 S0, the second group contained farms belonging to the size category of 7-10 S0, and the third group included farms belonging to the size category of 11-14 SO (Figure 4).

A methodological feature of data processing is the usage of Standard Output from 2010 to express the economic size of farms according to EU rules. From 2010 the SGM (Standard Gross Margin) is replaced by the SO. Standard output is a standardised production value related to a unit of agricultural production (one hectare of land or one livestock unit generated in usual weather and production conditions). $S G M$ reflects $(S G M=$ total production - direct variable costs) the income generating capacity of the corporate farms. SO reflects the output of the enterprises.

Those farms belong to the first group (3-6 S0), which had a standard production value between 4000 and 50000 EUR. During the examined period, 883 holdings have represented this observation, which is $46.5 \%$ of the total sample.

Technical efficiency of farms belonging to the first group was relatively low in the early 2000s. Then, the indicator almost doubled after the EU accession, which is attributed to the increase of the volume of subsidies. A large amount of financial resources was suddenly available for the farmers, spent on development, investment, and the modernization of the amortized machinery and equipment.

Technical efficiency had begun to decline starting from 2006, but it was still higher than the observed value at the beginning of the 2000s. The time series data from 2005, 2006, 2011 and 2013 were relatively high. They had

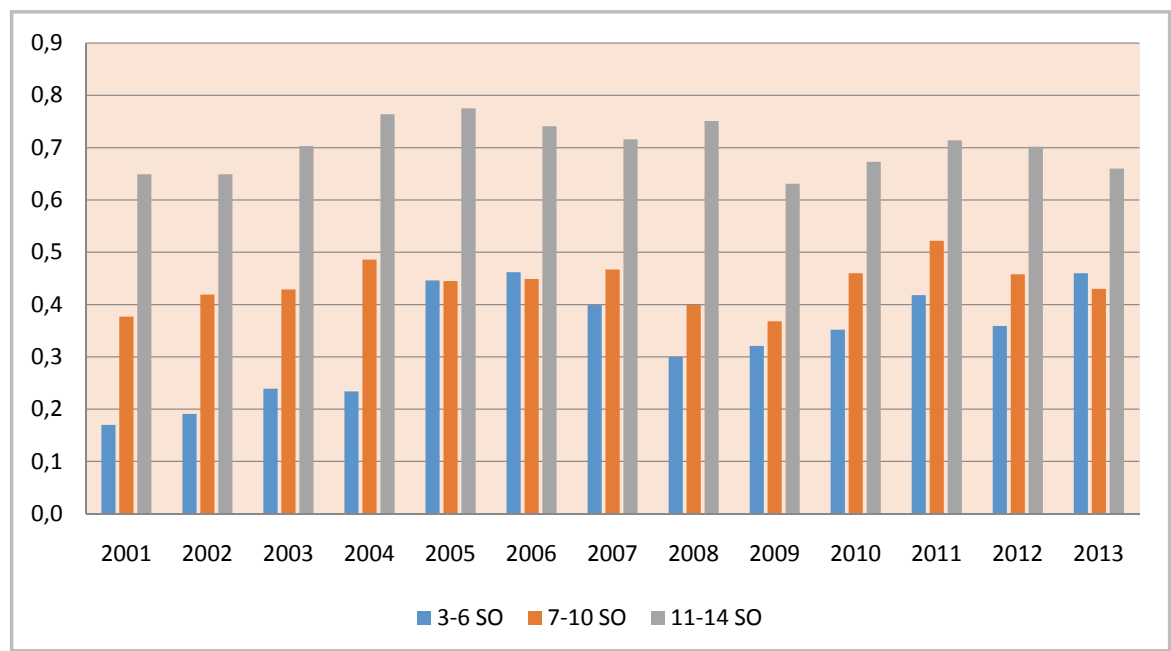

Figure 4 Improvement of technical efficiency by size categories (2001-2013) Source: Own edition based on FADN data, 2015 
reached or even exceeded the value of the technical efficiency in the whole sample (0.43).

The global economic crisis also had a big impact on these holdings. Figure 5 shows that the technical efficiency was 8-10 percentage points lower in 2008 and 2009 than a year ago. Naturally, not only the global economic crisis affected these farms. We must not ignore the climatic and natural conditions as well as the changes in the agricultural policy.

Those farms belong to the second group (7-10 S0), which had a standard production value between 50000 and 750000 EUR. During the examined period, 864 holdings have represented this observation, which is $45.5 \%$ of the total sample.

A new concept called crisis-bearing ability or crisis-tolerance was defined in connection with the efficiency examination. The following statement was formulated based on the results: larger holdings (7-10 S0) had a higher crisisbearing ability. The technical efficiency had only declined by 3 percentage points in their case in 2008 as a result of the crisis. The technical efficiency had decreased by 8-10 percentage points in the smaller farms.

The time series shows a balanced picture in which the year 2009 is considered as a major downturn (global financial crisis); however, the decrease is not significant. The absolute value of the technical efficiency is higher in these farms compared to the group of farms belonging to the first size category (3-6 S0).

Those farms belong to the third group (11-14 S0), which had a standard production value between 750000 - 3 million EUR. During the examined period, only 174 holdings have represented this observation, which is $6-10 \%$ of the total sample.

The technical efficiency is the highest in the farms belonging to this group among all farms analysed. The average value of the TE indicator was 0.7 , which is three tenths higher than the value of TE in farms belonging to the second size group (7-10 S0) and it is four tenths higher than the value of TE in farms belonging to the first group (3-6 S0). The technical efficiency of the biggest farm size (11-1450) plays a dominant role because the technical efficiency of these farms is the highest in the sample; however, their crisis-bearing ability is the lowest: their technical efficiency declined by 12 percentage points in 2009 compared to 2008.

We could partially confirm our previous statement, which said that the crisis-bearing ability in the bigger farms is higher compared to the smaller farms. The crisis-bearing ability in farms belonging to the second size group
(7-10 50) is higher than the crisis-bearing ability in holdings belonging to the smallest size group (3-6 S0). We stated that the crisis-bearing ability is the highest in farms belonging to the biggest size group (11-14 S0). The hypothesis of the inverse relationship between farm size and crisisbearing ability was not confirmed.

\section{Efficiency calculations by type of farming}

A sectorial efficiency analysis was made with four sectors between 2001 and 2013: arable crops production, pig breeding, dairy farming, and fruit production.

Almost half of the holdings in the FADN deal with arable crops production correlated to the ratio of crops and livestock production (65:35). It is necessary to make a clarification because the mixed farms also use agricultural land which greatly affects the high proportion of cropping.

As much as $3-4 \%$ of the FADN sample consists of pig breeding, while the proportion of dairy farms is nearly $7-10 \%$ in the sample. The fruit-growing farms represent $7-8 \%$ of the total sample, which means 160-170 farms.

The technical efficiency of arable crops production was very low at the beginning of the 2000s, but it increased later. As a result of the EU accession in 2004, a large amount of subsidies had arrived to the sector. The technical efficiency of farms had risen by seven percentage points by 2005 due to the increase of subsidies. The improvement was followed by a decline, which had the lowest point in 2009.

The impact of the global economic crisis can be seen in 2008 and 2009, which resulted in a 5 percentage point's decline of the technical efficiency. Farmers had to face the occurrence of extreme weather conditions in recent years. The production had declined due to droughts in 2007 and 2012. A very large amount of rainfall has resulted in the decrease of production in 2010.

The technical efficiency in the case of pig breeding was already high in the early 2000 s compared to the value of technical efficiency of the arable crops production, which was 2.5 times higher and it shows a relatively balanced picture. A modest decrease had occurred in 2008 and 2009 but this period was followed by a fast improvement. The average technical efficiency in the case of pig breeding was 0.44 in 2013.

The technical efficiency by dairy farming was the highest in 2001 compared to the other types of farming and it still had this position under the period examined. The technical efficiency in the case of pig farms has approached it, while arable crops production stayed largely below this level.

The average technical efficiency of dairy farms showed a value of 0.7 , higher values had occurred in two years only. The technical efficiency values were lower in all other years; however, it is noticeable that the technical efficiency values were relatively stable over the period 2001-2013.

The technical efficiency of fruit production had shown a strongly fluctuated picture between 2001 and 2013. The value of TE was the lowest (0.355) in the year of the EU accession (2004) and it was followed by a significant improvement. It had reached the lowest point (0.392) in 2009 and since then, it has been growing and stagnating in turn. The crisis-bearing capacity in the fruit production is low because there has occurred a 4 percentage point's decrease in terms of the technical efficiency due to the financial and economic world crisis, which can be stated significant.

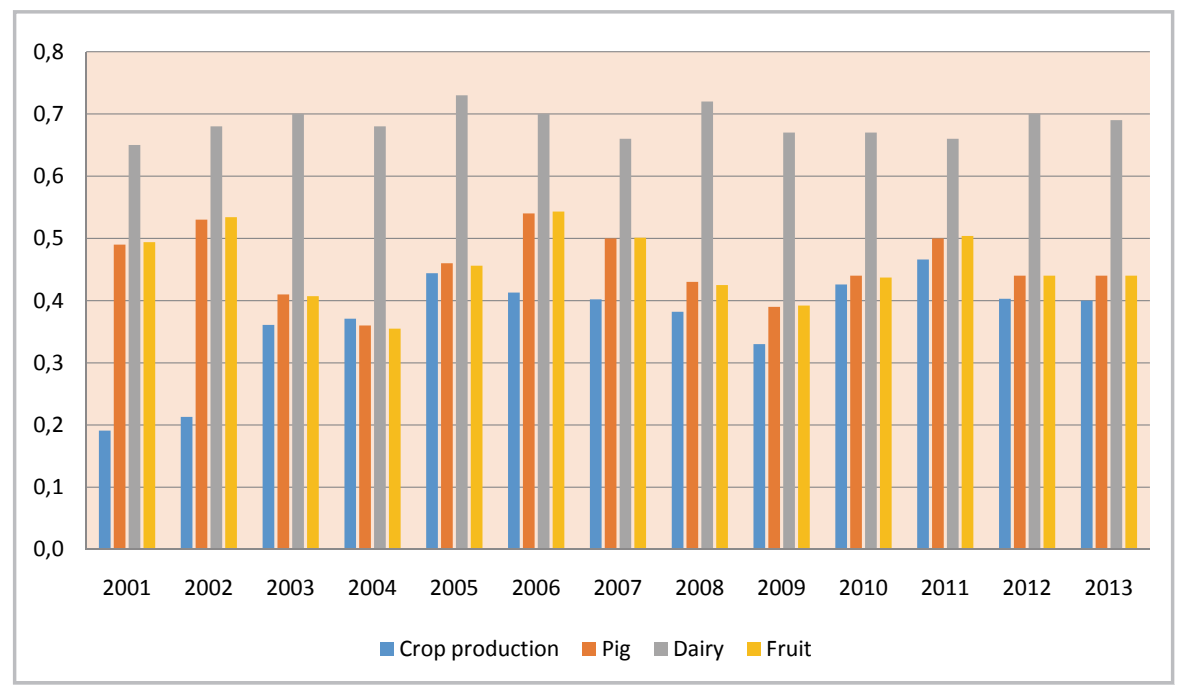

Figure 5 Improvement of technical efficiency by type of farming (2001-2013) Source: Own edition based on FADN data, 2015 
Summary findings are the following: the technical efficiency has improved after Hungary's accession to the EU in the case of all of the four groups (arable crops production, pig breeding, dairy farming, and fruit production). The technical efficiency has declined after the world crisis in each group.

\section{Conclusion}

Hungarian agriculture was a prosperous sector of the national economy before the transition. The political, economic and social transition (1989-1990) resulted in a rapid and radical workforce loss in the whole economy: 1.7 million workplaces were lost in the early 1990s, mainly in the productive sectors.

Agriculture discharged the largest number of employees (650 thousand people) and between 1990 and 2013, the sector's annual share in employment has fallen by three quarters, from $17.5 \%$ to $4.9 \%$. The rearrangement of the farm and property structure, the reduction in the technical and technological standards, the privatisation of land and the loss of its important markets made it vulnerable.

More than twenty years have elapsed since the radical political, economic and social transition in Hungary but there are still current questions like what is the role of agriculture in contributing to an increase in the GDP, solving the problems of employment especially in the rural areas, and ensuring a secure livelihood for the farmers. There is also an important question regarding the issue of economic groups that can meet the criteria of viability, subsistence, efficiency and competitiveness and the multifunctional role of agriculture, too.

Efficiency analysis was made (the output-oriented DEA-method) using FADN data based on legal forms, farm size and type of farming. We have first assumed that with the increasing farm size, the technical efficiency has also been improving and secondly, that the technical efficiency of arable crops production is lower compared to animal husbandry. The results have shown - when we examined all the farms in the sample - that the technical efficiency was very low.

The technical efficiency is the best when its value is close to 1 . Our results have shown that the technical efficiency was the highest in the biggest farms (11-14 S0), in the pig breeding and in the dairy farms, so our assumptions were correct.

We made the following summarising statements in connection to our calculations:

$\square$ The increasing farm size can work towards the improving technical efficiency.

$\square$ The technical efficiency was the highest by the corporate farms and by those farms who deal with animal husbandry; it is closer to the one. The technical efficiency was very low by arable crops production and by the individual farms.

$\square$ The technical efficiency has stagnated by both legal forms over the last three years. The gap between the individual and corporate farms has increased after the economic crisis in terms of the technical efficiency.

$\square$ The average technical efficiency is about 0.4 by arable crops production, which is much lower compared to the animal husbandry.

$\square$ The average technical efficiency is about 0.5 by fruit production which is also lower compared to the animal husbandry.

The research has also identified the potential factors affecting the technical efficiency change, which are as follows: legal form, farm size, and type of farming, employment in the farm (annual work unit), agricultural policy tools, and subsidy level.

In our opinion, the weight of small family farms is relatively small in the whole performance of the agricultural sector in Hungary but their role in employment is still significant and high especially in rural areas. Small family farms usually cultivate only few hectares but their importance in supplementing the family incomes or generating modest surplus is unquestionable.

\section{References}

AFRIAT, S. N. 1972. Efficiency estimation of production functions. In International Economic Review, vol. 13, 1972, no. 3, pp. 568-598.

AIGNER, D. J. - LOVELL, C. A. K. - SCHMIDT, P. 1977. Formulation and estimation of stohastic frontier production functions. In Journal of Econometrics, vol. 6, 1977, pp. 21-37.

ALLEN, R. - ATHANASSOPOULOS, A. - DYSON, R. G. - THANASSOULIS, E. 1997. Weights Restrictions and Value Judgements in Data Envelopment Analysis: Evolution, Development and Future Directions, Annals of Operational Research, vol. 73, 1997, pp. 13-34.

BAKUCS, Z. - FERTŐ, I. - FOGARASI, J. - LATRUFFE, L. - DESJEUX, Y. - MATVEEV, E. MARONGIU, S. - DOLMAN, M. - SOBOH, R. 2011. EU farms' technical efficiency and productivity change in 1990-2006. In The $85^{\text {th }}$ Annual Conference of the Agricultural Economics Society Warwick, $18^{\text {th }}-20^{\text {th }}$ April 2011. p. 35.

BARÁTH, L. - FERTÖ, I. 2014. Agricultural Productivity in the EU: A TFP Comparison between the Old (EU-15) and New (EU-10) EU Member States. 142 ${ }^{\text {nd }}$ EAAE Seminar, May 29-30, Budapes : Corvinus University of Budapest, 2014. p. 18.

BANKER, R. - CHARNES, A. - COOPER, W. W.1984. Some models for estimating technical and scale efficiencies in DEA. In Management Sciences, vol. 30, 1984, 1984, no. 9, pp. 1078-1092.

COOPER, W.W. - SEIFORD, L. M. - TONE, K. 2000. Data Envelopment Analysis: A Comprehensive Text with Models, Applications, References and DEA-Solver Software, Kluwer Academic Publishers : Boston, 2000.

COOPER, W. W. - SEIFORD, L. M. - ZHU, J. 2004. Data Envelopment Analysis. In International Series in Operations Research \& Management Science, vol. 71, 2004, no. 1, 2004, pp. 1-39.

FARREL, M. J.1957. The measurement of productive efficiency. In Journal of Royal Statistical Society, 1957, no. 120, pp. 253-281.

FOGARASI, J. - LATRUFFE, L. 2009. Technical efficiency in dairy farming: A comparison of France and Hungary in 2001-2006. In Studies in Agricultural Economics, 2009, no. 110, pp. 75-84.

GORTON, M. - DAVIDOVA, S. 2001 The international competitiveness of CEEC agriculture. In World Economy, vol. 24, 2001, no. 2, pp. 185-200.

GORTON, M. - DAVIDOVA, S. 2004. Farm productivity and efficiency in the CEE applicant countries: a synthesis of results. In Agricultural Economics, 2004, no. 30, pp. 1-16.

HOCKMANN, H. - PIENIADZ, A. 2007. Farm heterogeneity and efficiency in Polish agriculture: a stohastic frontier analysis. 104 ${ }^{\text {th }}$ EAAE Seminar, Budapest : Corvinus University of Budapest, 6-8 September 2007.

CHARNES, A. - COOPER, W. W. - RHODES, E.1978. Measuring the efficiency of decision making units. In European Journal of Operational Research, 1978, no. 2, pp. 429-444.

CHARNES, A. - COOPER, W. W. - LEWIN, A. Y. - SEIFORD, L. M.1994. Data Envelopment Analysis: Theory, Methodology and Application, Kluwer Academic Publishers, Boston/ Dordrecht/London, 1994.

KAPRONCZAI, I. - KESZTHELYI, SZ. - TAKÁCS, I. 2014. Changes in the efficiency and profitability of farms. In Gazdálkodás, vol. 58, 2014, no. 3, pp. 222-236.

KEMÉNY, G. - FELKAI, B. 0. - FOGARASI, J. - KOVÁCS, G. - MERKEL, K. - TANÍTÓ, D. TÓTH, K. - TÓTH, 0. 2010. Financing channels of the Hungarian agriculture and Impacts of the Financial Crisis on Them. In Agricultural Books, Research Institute of Agricultural Economics, 2010. p. 149.

KESZTHELYI, Sz. - PESTI, Cs. 2010. Results of Hungarian FADN farms; Agricultural Informations; Research Institute of Agricultural Economics, Budapest, 2012. p. 51.

LATRUFFE, L. 2010. Competitiveness, Productivity and Efficiency in the Agricultural and Agri-Food Sectors; OECD Food, Agriculture and Fisheries Working Papers 30. p. 63.

MARKOVICS - SOMOGYI, R.-BOKOR, Z. 2010. Application of DEA-method in logistics (A Data Envelopment Analysis (DEA) módszeralkalmazásilehetőségei a logisztikában) Budapesti Müszakiés Gazdaságtudományi Egyetem Közlekedésgazdasági Tanszék, 2010. p. 6.

MATHIJS, E. - SWINNEN, F. M. 1997. The economics of agricultural decollectivization in East Central Europe and the Former Soviet Union. In Economic Development and Cultural Change, vol. 47, 1997, no. 1, pp. 1-26.

SZEMÁN, J. 2011. The impact of the financial crisis of the capital structure of the Hungarian companies. Miskolci Egyetem. In Gazdaságtudományi Kar, 2011, pp. 136-146. http:// www.irisro.org/gazdasagtan2013januar/G214SzemanJudit.pdf

TARIM, A. - KARAN, B. 2001. Data Envelopment Analysis in Performance Evaluation.In International Journal of Government Auditing, vol. 24, 2001, no. 4, p. 24.

\section{Contact addresses}

Orsolya Tóth Ph.D., Research Institute of Agricultural Economics, Rural Policy Department, Budapest, Hungary, e-mail: toth.orsolya@aki.gov.hu 